\title{
Pemberantasan Pungutan Liar pada Pelayanan Publik dari Perspektif Sosiologi Hukum
}

\author{
Eko Budi $\mathbf{S}^{1}$ \\ Fakultas Hukum Universitas Batanghari Jambi, Jl. Slamet Riyadi Broni - Jambi \\ Telpon: (0741) 65351 \\ Email: ekobudi1999@yahoo.co.id
}

\begin{abstract}
Abstrak. Fenomena pungutan liar yang terjadi di Lembaga/Instansi Pemerintah melibatkan oknum dan masyarakat, yang menjadikan suatu budaya sosial yang dipelihara sehingga menjadi hal yang wajar. Hal ini sangat mencoreng Lembaga/Instansi yang menyediakan layanan kepada masyarkat tersebut. Permaslahan pelayanan publik sangat komplek sehingga masyarakat yang membutuhkan dan penyelenggara pelayanan publik cenderung melanggengkan pungutan liar tersebut. Praktik pungutan liar saat ini telah merusak sendi-sendi kehidupan bermasyarakat dan menyebabkan kerugian kepada masyarakat yang membutuhkannya. Ibarat fenomena gunung es, pungutan liar hanya nampak jika ketahuan setelah adanya pengaduan/tindakan hukum oleh aparat penegak hukum, namun sebenarnya yang belum diadukan/terungkap masih banyak. Tujuan dari penelitian ini adalah untuk untuk memberikan sumbangan pemikiran dalam rangka pemberantasan pungutan liar pada sektor pelayanan publik melalui pendekatan sosiologi hukum. Tipe yang digunakan dalam penelitian adalah yuridis normatif dengan menggunakan pendekatan perundangundangan.
\end{abstract}

Kata kunci: Pungutan liar, pelayanan publik, sosiologi hukum.

\begin{abstract}
The phenomenon of illegal levies that occur in Government Institutions/Institutions involves individuals and society, which makes a social culture maintained so that it becomes a natural thing. This greatly tarnished the Institutions/Institutions that provided services to the community. The issue of public service is very complex so that people in need and providers of public services tend to perpetuate these illegal levies. Current practices of illegal levies have damaged the joints of community life and caused harm to the people who need them. Like an iceberg phenomenon, illegal fees only appear if caught after legal complaints / actions by law enforcement officials, but there are still many that have not been reported / revealed. The purpose of this study is to contribute ideas in the context of eradicating illegal levies in the public service sector through a legal sociology approach. The type used in the study is normative juridical using the statutory approach.
\end{abstract}

Keywords: Illegal levies, public services, legal sociology.

\section{PENDAHULUAN}

Upaya pemerintah untuk memberantas pungli sesungguhnya bukan sesuatu yang baru. Presiden pertama Republik Indonesia, Soekarno pernah membentuk Badan Pengawas Kegiatan Aparatur Negara (Bapekan) melalui Peraturan Presiden Nomor 1 Tahun 1959 dengan ketua Sri Sultan HB IX. Bapekan bertugas untuk menerima dan menyelesaikan pengaduan, utamanya pengaduan tentang korupsi dan pungli. Kemudian pada tahun 1977 di masa Pemerintah Orde Baru pernah dibentuk tim Operasi Tertib (Opstib) melalui Instruksi Presiden Nomor 9 Tahun 1977 yang dikomandoi Kepala Staf Kopkamtib Laksamana Sudomo untuk memberantas pungli. ${ }^{2}$ Berlanjut di era Reformasi pada masa pemerintahan Susilo Bambang Yudhoyono, pernah pula dibentuk Satgas Pemberantasan Mafia Hukum melalui Keputusan Presiden Nomor 37 Tahun 2009. Lembaga-lembaga yang disebutkan tersebut semuanya tidak ada yang berumur panjang. Gebrakan hanya terjadi pada awal masa pembentukan. Pungli pun terus berlanjut hingga kini.

Apa yang dilakukan pemerintah melalui pembentukan satgas dan penerbitan surat edaran merupakan hal yang patut diapresiasi. Namun demikian, dengan berkaca pada sejarah, hal itu hanya akan mengulang kegagalan upaya-upaya sebelumnya jika langkah pembenahan yang dilakukan berjalan secara parsial, ad hoc, dan hangat-hangat tahi ayam. Pembentukan satgas dan penerbitan surat edaran akan menjadi hal yang bersifat seremonial dan gertak sambal jika tidak ditopang dengan perbaikan yang bersifat struktural dan berkelanjutan. Dengan kata lain, penyelesaian hendaknya dilakukan secara sistematis dan menyeluruh.

\footnotetext{
${ }^{1}$ Dosen, Pada Fakultas Hukum, Universitas Batanghari Jambi.

${ }^{2}$ Antonius Galih Prasetyo, Memberantas Pungli Secara Sistemik, Inagara Magazin, Vol. I No. 2, Desember 2016 , hal. 50.
} 
Sampai bulan Oktober 2018, Satgas Saber Pungli telah menerima laporan pengaduan sebanyak 36.427 laporan/ pengaduan. Rinciannya yaitu laporan melalui SMS 1193 (23.440 SMS), email (6.61), aplikasi website (2.877), call center 193 (2.325), melalui surat (965), dan laporan secara langsung (179 pengaduan). Dari laporan pengaduan tersebut, masalah yang paling banyak dilaporkan yaitu terkait masalah pelayanan masyarakat $(50 \%)$, pendidikan $(20 \%)$, hukum $(8 \%)$, perijinan, kepegawaian, pengadaan barang dan jasa, dan lain-lain masing-masing (5\%). Sedangkan intansi yang paling banyak dilaporkan adalah Kemendagri, Kemendikbud, Polri, Kemenhub dan Kementerian ATR/BPN. Untuk daerah yang banyak dilaporkan oleh masyarakat adalah Provinsi Jawa Barat, Jawa Timur, DKI Jakarta, Banten dan Sumatera Utara. ${ }^{3}$

Untuk pokja penindakan Satgas, UPP Kementerian/Lembaga dan daerah telah melaksanakan sebanyak 7.439 kegiatan OTT, dengan jumlah tersangka sebanyak 12.146 orang. Dengan rincian: proses lidik/sidik (3.191 kasus), P19 (40 kasus), P21 (286 kasus), tahap penuntutan (3 kasus), dilaksanakan sidang (66 kasus), sudah divonis (160 kasus), SP3 (28 kasus), dan 3.665 kasus diserahkan kepada instansi terkait untuk dilakukan penindakan secara internal. Sedangkan jumlah barang bukti hasil OTT di seluruh Indonesia sebanyak Rp 320.383.285.082,00. Nilai perolehan terbesar pada UPP Kaltim yaitu Rp 298,6 miliar dan paling kecil yaitu UPP Kalimantan Utara sebanyak Rp 32 juta lebih.

Dari data tersebut, bahwa pungutan liar (pungli) kian merebak dari waktu ke waktu. Isu dan jutaan fakta turut membuka kedok hitam para pelaku yang notabene aparatur negara. Mirisnya, para aparatur negara disanjung bak pangeran di balik sindikat tersebut. Aparatur negara menempati strata tertinggi di balik jutaan makar yang dilakoni. Tidak heran, jika makar yang mereka lakoni bersama kelompok asuhannya berkarakter kamuflase dan bermuara pada aksi koruptif. Kiprah dan ruang gerak aparatur negara yang sempat terjebak di balik sindikat pungli menandakan sebuah gejala sosial berupa kemerosotan akhlak dan moral.

Dengan demikian pungli menjadi ancaman yang serius bagi bangsa Indonesia. Di sini kita patut mengingat filosofi dasar dari pelayanan publik itu sendiri. Pemerintah dibentuk salah satunya untuk memberikan pelayanan publik pada warganya. Legitimasi dari masyarakat didapatkan manakala pemerintah mampu menjalankan dengan baik tugas utamanya tersebut. Sebagai salah satu batu sendi yang membentuk raison d'etre dari keberadaan pemerintah, maka sudah selayaknya pelayanan publik dijalankan dengan semestinya sesuai asas universal dalam negara demokrasi dan beradab. Rambu-rambu mengenai hal ini telah diatur secara gamblang dan normatif dalam Undang-undang Nomor 28 Tahun 1999 tentang Penyelenggaraan negara yang bersih dari korupsi, kolusi, dan nepotisme (KKN) dan Undang-undang Nomor 25 Tahun 2009 tentang Pelayanan Publik.

\section{METODE PENELITIAN}

Metode penulisan yang digunakan adalah metode penulisan deduktif yaitu dengan cara pemaparan secara umum untuk mendapatkan kesimpulan secara khusus, tipe yang digunakan adalah yuridis normatif yang bersifat deskriptif analitik, untuk memperoleh gambaran secara menyeluruh dan mendalam serta melakukan analisis terhadap permasalahan yang dibahas.

Untuk menjawab permasalahan maka dilakukan pengumpulan bahan hukum melalui studi kepustakaan berupa bahan hukum primer, sekunder dan tersier, bahan-bahan tersebut kemudian diinventarisasi dan diidentifikasi, teknis analisis dilakukan secara interpretasi, yaitu bahan hukum diinterpretasikan dan dijabarkan dengan mendasarkan pada suatu norma dan pendekatan konsep kriminologi, sedangkan penarikan kesimpulan dilakukan dengan menggunakan metode penalaran secara deduktif.

\section{HASIL DAN PEMBAHASAN}

\section{Pungli Dalam Kajian Hukum Pidana}

Pungutan liar adalah perbuatan yang dilakukan oleh seseorang atau Pegawai Negeri atau Pejabat Negara dengan cara meminta pembayaran sejumlah uang yang tidak sesuai atau tidak berdasarkan

${ }^{3}$ Data dari Satgas Saber Pungli Pusat tahun 2016 - 2018, sumber dari: https://polkam.go.id/tiga-tahun-berjalan-satgassaber-pungli-lakukan-7-439-ott/ diakses tanggal 12 November 2018. 


\section{Eko Budi S}

peraturan yang berkaitan dengan pembayaran tersebut. ${ }^{4}$ Pungutan liar termasuk dalam kategori kejahatan jabatan, di mana dalam konsep kejahatan jabatan dijabarkan bahwa pejabat demi menguntungkan diri sendiri atau orang lain, menyalahgunakan kekuasaannya untuk memaksa seseorang untuk memberikan sesuatu, untuk membayar atau menerima pembayaran dengan potongan, atau untuk mengerjakan sesuatu bagi dirinya sendiri. ${ }^{5}$

Pungutan liar juga merupakan maladministrasi yang dilakukan oleh pejabat publik atau penyelenggara pelayanan publik. Sebagai contoh, jika ada oknum pemerintahan yang memungut biaya dalam pengurusan akta kelahiran, maka bisa disebut dengan pungutan liar karena bertentangan dengan peraturan yang lazim. Pungutan tanpa dasar hukum yang sah dapat dikatakan sebagai kegiatan maladministrasi. Maladministrasi menurut Undang-Undang Nomor 37 Tahun 2008 tentang Ombudsman Republik Indonesia diartikan sebagai perilaku atau perbuatan melawan hukum, melampaui wewenang, menggunakan wewenang untuk tujuan lain dari yang menjadi tujuan wewenang tersebut, termasuk kelalaian atau pengabaian kewajiban hukum dalam penyelenggaraan pelayanan publik yang dilakukan oleh Penyelenggara Negara dan pemerintahan yang menimbulkan kerugian materiil dan/atau immateriil bagi masyarakat dan orang perseorangan.

Pungli terjadi karena ada dua pihak yang terlibat yaitu antara penyelenggara pelayan publik dan pengguna jasa layanan publik, mereka melakukan transaksi rahasia maupun terang-terangan. Oleh sebab itu, pungli pada umumnya terjadi pada tingkat pelayanan kepada masayarakat, dilakukan secara singkat dengan imbalan langsung yang biasanya berupa uang. Adapun permasalahan-permasalahan dalam pelayanan publik, diantaranya adalah: masih terbatasnya kualitas layanan publik, kurang kesadaran dan keinginan aparat penyelenggara negara untuk menjalankan/memberikan pelayanan publik yang baik karena tidak ada manfaatnya bagi mereka, rendahnya kesadaran masyarakat untuk taat aturan dan kurangnya budaya antri, belum banyak digunakannya teknologi informasi di pelayanan publik, belum meratanya pemahanman pelayanan publik yang prima dimata penyelenggara negara, lemahnya pelaksanaan hukum/aturan yang ada.

Permasalahan ini diperparah lagi dengan kondisi masyarakat saat ini, seperti: kualitas pelayanan publik masih identik dengan hubungan kekerabatan atau tingkat sosial, pelayanan publik masih terkait dengan "fulus" ada uang, ada layanan prima, masyarakat banyak yang apatis dan frustasi terhadap kualitas pelayanan publik, apatis dan terbuka lebarnya media untuk protes maka reaksi publik cenderung asal bunyi dan sulit untuk melakukan perubahan di jajaran penyelenggara pelayan publik, masyarakat masih mudah terpengaruh oleh gosip dan mudah anarkis ketika kualitas layanan publik buruk serta banyak kalangan atas yang melakukan pungli bebas dari tuntutan hukum. ${ }^{6}$

Menurut Barda Nawawi Arief menyatakan bahwa upaya penanggulangan kejahatan pada hakikatnya merupakan bagian integral dari upaya perlindungan masyarakat (social defence) dan upaya mencapai kesejahteraan masyarakat (social welfare). Oleh karena itu, dapat dikatakan bahwa tujuan akhir kebijakan adalah perlindungan masyarakat untuk mencapai kesejahteraan masyarakat. ${ }^{7}$

Dalam pungutan liar, yang menjadi unsur-unsur objektif, telah diatur dalam rumusan tindak pidana korupsi pada Pasal 12 huruf e UU Nomor 20 Tahun 2001 tentang Pemberantasan Tindak Pidana Korupsi (UU PTPK) yaitu Pasal 423 KUHP sebagai berikut:

a. Pegawai negeri atau penyelenggara negara (deambtenaar)

b. Menyalahgunakan kekuasaan (misbruik van gezag);

c. Memaksa seseorang (iemand dwigen om) untuk:

1) Memberikan sesuatu (iets af geven);

2) Membayar (uitbetaling);

${ }^{4}$ Hisam Sam, Pengertian Pungli dan Faktor Penyebabnya, https://www.dosenpendidikan.com/pungutan-liar-punglipengertian-faktor-penyebab-tindak-pidana/, diakses tanggal 2 Februari 2018.

${ }^{5}$ Moh Toha Solahuddin, Pungutan Liar dalam Perspektif Tindak Pidana Korupsi, Majalah Paraikatte, Vol. 26, Triwulan III, 2016, hal. 2.

${ }^{6}$ Eko Budi, Meningkatkan Kinerja UPP Kabupaten/Kota dalam Memberantas Pungli Melalui Strategi Pembinaan dan Penindakan, Makalah diberikan pada Raker Lintas Unit Kerja Saber Pungli se-Propinsi Jambi, tanggal 14-15 November 2018.

${ }^{7}$ Reza Iswanto, Kebijakan Nonpenal oleh Badan Narkotika Nasional Provinsi Jambi terhadap Penyalahguna Narkotika, Jurnal Wajah Hukum, Volume 2 Nomor 2 (Oktober 2018), hal. 167. 
3) Menerima pembayaran dengan potongan, atau (eene terughouding genoegen nemenbij eene uitbetaling);

4) Mengerjakan sesuatu bagi dirinya sendiri (een persoonlijken dienst verrichten).

Sedangkan yang menjadi unsur-unsur subjektif, dalam hal ini diatur dalam rumusan tindak pidana korupsi pada Pasal 12 huruf e dalam UU PTPK pada Pasal 423 KUHP adalah:

a. Atau dengan maksud untuk (met het oogmerk om) menguntungkan diri sendiri atau orang lain secara melawan hukum (zich of een ander wederrechtelijk te bevoordelen);

b. Menguntungkan secara melawan hukum (wederrechtelijk te bevoordelen)

Penjelasan beberapa Pasal di dalam KUHP yang dapat mengakomodir perbuatan pungutan liar adalah sebagai berikut:

Pasal 368 KUHP:

"Barang siapa dengan maksud untuk menguntungkan diri sendiri atau orang lain secara melawan hukum, memaksa orang lain dengan kekerasan atau ancaman kekerasan, untuk memberikan sesuatu barang, yang seluruhnya atau sebagian adalah milik orang lain, atau supaya memberikan hutang maupun menghapus piutang, diancam, karena pemerasan, dengan pidana penjara paling lama sembilan tahun."

Pasal 423 KUHP:

"Pegawai negeri yang dengan maksud menguntungkan diri sendiri atau orang lain secara melawan hukum, dengan menyalah gunakan kekuasaannya memaksa orang lain untuk menyerahkan sesuatu, melakukan suatu pembayaran, melakukan pemotongan terhadap suatu pembayaran atau melakukan suatu pekerjaan untuk pribadi sendiri, dipidana dengan pidana penjara selama-lamanya enam tahun."

Menurut ketentuan yang diatur dalam Pasal 12 UU PTPK, kejahatan yang diatur dalam Pasal 423 KUHP merupakan tindak pidana korupsi, sehingga sesuai dengan ketentuan pidana yang diatur dalam Pasal 12 huruf e dari UU PTPK, pelakunya dapat dipidana dengan pidana penjara seumur hidup atau dengan pidana penjara paling singkat empat tahun dan paling lama dua puluh tahun dan pidana denda paling sedikit dua ratus juta rupiah dan paling banyak satu miliar rupiah. Tindak pidana yang diatur dalam Pasal 423 KUHP dengan maksud untuk menguntungkan diri sendiri atau orang lain secara melawan hukum, merupakan suatu bijkomend oogmerk, sehingga oogmerk atau maksud tersebut tidak perlu telah terlaksana pada waktu seorang pelaku selesai melakukan perbuatan-perbuatan yang terlarang di dalam pasal ini.

Dari rumusan ketentuan pidana dalam Pasal 423 KUHP di atas, dapat diketahui bahwa yang dilarang di dalam pasal ini ialah perbuatan-perbuatan dengan menyalahgunakan kekuasaan memaksa orang lain:

a. Untuk menyerahkan sesuatu;

b. Untuk melakukan suatu pembayaran;

c. Untuk menerima pemotongan yang dilakukan terhadap suatu pembayaran;

d. Untuk melakukan suatu pekerjaan untuk pribadi pelaku.

Perbuatan-perbuatan dengan menyalahgunakan kekuasaan memaksa orang lain untuk menyerahkan sesuatu, melakukan suatu pembayaran, menerima pemotongan yang dilakukan terhadap suatu pembayaran dan melakukan suatu pekerjaan untuk pribadi pelaku itu merupakan tindak pidana materil, hingga orang baru dapat berbicara tentang selesai dilakukannya tindak-tindak pidana tersebut, jika akibat yang tidak dikehendaki oleh undang-undang karena perbuatan-perbuatan itu telah timbul atau telah terjadi. Karena tidak diberikannya kualifikasi oleh undang-undang mengenai tindak-tindak pidana yang diatur dalam Pasal 423 KUHP, maka timbullah kesulitan di dalam praktik mengenai sebutan apa yang harus diberikan pada tindak pidana tersebut.

Sejak diperkenalkannya kata pungutan liar oleh seorang pejabat negara, tindak pidana-tindak pidana yang dimaksudkan dalam Pasal 423 KUHP sehari-hari disebut sebagai "pungutan liar". Pemakaian kata pungutan liar itu ternyata mempunyai akibat yang sifatnya merugikan bagi penegakan hukum, karena orang kemudian mempunyai kesan bahwa menurut hukum itu seolah-olah terdapat gradasi mengenai perbuatan-perbuatan memungut uang dari rakyat yang dilarang oleh undang-undang, yakni dari tingkat yang seolah-olah tidak perlu dituntut menurut hukum pidana yang berlaku hingga tingkat yang 
seolah-olah harus dituntut menurut hukum pidana yang berlaku, sedang yang dewasa ini biasa disebut pungutan liar itu memang jarang membuat para pelakunya diajukan kepengadilan untuk diadili, melainkan cukup dengan diambilnya tindakan-tindakan disipliner atau administratif terhadap mereka, padahal kita semua mengetahui bahwa yang disebut pungutan liar itu sebenarnya merupakan tindak pidana korupsi seperti yang antara lain diatur dalam Pasal 12 huruf e dan f UU PTPK.

Kebiasaan tidak mengajukan para pegawai negeri yang melanggar larangan-larangan yang diatur dalam Pasal 423 atau Pasal 425 KUHP Jo. Pasal 12 UU PTPK ke pengadilan untuk diadili, dan sematamata hanya mengenakan tindakan-tindakan administratif terhadap mereka itu perlu segera dihentikan, karena kebiasaan tersebut sebenarnya bertentangan dengan beberapa asas yang dianut oleh UndangUndang Hukum Acara Pidana kita yang berlaku, yakni:

a. Asas legalitas, yang menghendaki agar semua pelaku sesuatu tindak pidana itu tanpa kecuali harus dituntut menurut undang-undang pidana yang berlaku dan diajukan ke pengadilan untuk diadili;

b. Asas verbod van eigen richting atau asas larangan main hakim sendiri, yakni menyelesaikan akibat hukum dari suatu tindak pidana tidak melalui proses peradilan.

Adapun maksud untuk tidak mengajukan tersangka ke pengadilan untuk diadili, maka maksud tersebut harus dilaksanakan sesuai dengan peraturan perundang-undangan yang berlaku. Menurut peraturan perundang-undangan yang berlaku di Indonesia, suatu perkara itu hanya dapat dikesampingkan untuk kepentingan umum, dan bukan untuk kepentingan tersangka/korps atau organisasi tersangka. Perbuatan menyampingkan perkara itu tidak dapat dilakukan setiap orang dengan jabatan atau pangkat apa pun, karena menurut ketentuan yang diatur dalam Pasal 35 huruf c Undang-Undang Nomor 16 Tahun 2004 tentang Kejaksaan Republik Indonesia, sebagaimana dalam LN Tahun 2004 No. 67, yang berwenang menyampingkan suatu perkara berdasarkan kepentingan umum itu hanyalah Jaksa Agung saja. Mengenai pengertiannya sebagai uang, perbuatan dengan menyalahgunakan kekuasaan memaksa orang menyerahkan sesuatu itu dalam contoh sehari-hari dapat dilihat dalam bentuk pungutan di jalanjalan raya, di pos-pos pemeriksaan, di instansi-instansi pemerintah, bahkan yang lebih tragis lagi adalah bahwa pungutan-pungutan seperti itu juga dilakukan oleh para pendidik baik terhadap sesama pendidik maupun terhadap anak-anak didik mereka.

Akan tetapi, tidak setiap pungutan seperti yang dimaksudkan di atas itu merupakan pelanggaran terhadap larangan yang diatur dalam Pasal 423 KUHP jo. Pasal 12 UU PTPK, karena jika pungutan tersebut ternyata telah dilakukan karena pegawai negeri yang memungut pungutan itu telah melakukan sesuatu atau mengalpakan sesuatu di dalam menjalankan tugas jabatannya yang sifatnya bertentangan dengan kewajibannya, maka perbuatannya itu merupakan pelanggaran terhadap larangan-larangan yang diatur dalam Pasal 419 angka 2 KUHP jo. Pasal 12 huruf e UU PTPK. Perbuatan yang dilarang dalam Pasal 423 KUHP ialah dengan menyalahgunakan kekuasaan memaksa orang lain melakukan suatu pembayaran. Sebenarnya tidak seorang pun dapat dipaksa melakukan suatu pembayaran kecuali jika pemaksaan untuk melakukan pembayaran seperti itu dilakukan berdasarkan suatu peraturan undangundang.

Pada pasal 425 KUHP, kejahatan-kejahatan yang diatur yakni menerima atau melakukan pemotongan terhadap suatu pembayaran seolah-olah merupakan utang kepada dirinya atau kepada pegawai negeri yang lain atau kepada sesuatu kas umum dan lain-lain, yang dilakukan oleh pegawai negeri dalam menjalankan tugas jabatannya. Perbuatan-perbuatan yang dilarang dalam pasal ini:

a. Pegawai Negeri yang di dalam menjalankan tugas jabatannya meminta, menerima, atau melakukan pemotongan terhadap suatu pembayaran seolah-olah merupakan utang kepada dirinya atau kepada pegawai negeri yang lain atau kepada sesuatu kas umum, sedang ia mengetahui bahwa utang seperti itu sebenarnya tidak ada;

b. Pegawai Negeri yang di dalam menjalankan tugas jabatannya meminta atau menerima jasa-jasa secara pribadi atau penyerahanpenyerahan seolah-olah orang berutang jasa atau penyerahan seperti itu, sedang ia mengetahui bahwa utang seperti itu sebenarnya tidak ada;

c. Pegawai Negeri yang di dalam menjalankan tugas jabatannya menguasai tanah-tanah negara yang di atasnya terdapat hak pakai bangsa Indonesia dengan merugikan orang yang berhak, seolah-olah yang ia lakukan itu sesuai dengan peraturan-peraturan yang berlaku, sedang ia mengetahui bahwa dengan 
melakukan tindakan seperti itu sebenarnya ia telah bertindak secara bertentangan dengan peraturanperaturan tersebut.

Tentang pungutan liar telah dijelaskan dalam Undang-Undang No. 31 tahun 1999 Jo. UndangUndang Nomor 20 Tahun 2001. Adapun penjelasan beberapa Pasal yang dapat mengakomodir perbuatan pungutan liar adalah sebagai berikut:

a. Pasal 12 huruf e "Pegawai negeri atau penyelenggara negara yang dengan maksud menguntungkan diri sendiri atau orang lain secara melawan hukum atau dengan menyalahgunakan kekuasaannya, memaksa seseorang memberikan sesuatu, membayar, atau menerima pembayaran dengan potongan, atau untuk mengerjakan sesuatu bagi dirinya sendiri."

b. Pasal 12 huruf f "Pegawai negeri atau penyelenggara negara yang pada waktu menjalankan tugas, meminta, menerima, atau memotong pembayaran kepada pegawai negeri atau penyelenggara negara yang lain atau kepada kas umum, seolah-olah pegawai negeri atau penyelenggara negara yang lain atau kas umum tersebut mempunyai utang kepadanya, padahal diketahui bahwa hal tersebut bukan merupakan utang".

\section{Kajian Sosiologi Hukum Tentang Faktor-Faktor Penyebab Pungli}

Kehadiran hukum dalam masyarakat sangat penting, hukum merupakan bagian yang tidak terpisahkan dari kehidupan masyarakat, sehingga ada sebuah adagium yang dikenal dalam ilmu hukum, yaitu ubi societas ibi ius, dimana ada masyarakat maka disitu ada hukum. Fungsi hukum sebagai sosial kontrol merupakan aspek yuridis normatif dari kehidupan masyarakat. Sebagai alat pengendali sosial, hukum dianggap berfungsi untuk menetapkan tingkah laku yang baik dan tidak baik atau perilaku yang menyimpang dari hukum, dan sanksi hukum terhadap orang yang mempunyai perilaku tidak baik. Namun, apa yang dianggap baik oleh seseorang belum tentu baik menurut yang lainnya.

Sosiologi hukum menurut Soerjono Soekanto adalah cabang ilmu pengetahuan yang secara analitis dan empiris menganalisis atau mempelajari hubungan timbal balik antara hukum dengan gejala-gejala sosial lainnya. ${ }^{8}$ Sosiologi hukum merupakan suatu ilmu yang muncul dari perkembangan ilmu pengetahuan hukum dan dapat diketahui dengan mempelajari fenomena sosial dalam masyarakat yang tampak aspek hukumnya.

Bila dilihat dari karakteristik kajian sosiologi hukum, disebutkan bahwa sosiologi hukum berusaha memberikan deskripsi dalam praktik-praktik hukum. Sosiologi hukum bertujuan untuk menjelaskan mengapa suatu praktik-praktik hukum di dalam kehidupan sosial masyarakat itu terjadi, sebab-sebabnya, faktor-faktor yang mempengaruhi dan lain sebagainya. Sosiologi hukum senantiasa menguji kesahihan empiris dari suatu peraturan atau pernyataan hukum, sehingga mampu memprediksi suatu hukum yang sesuai dan/atau tidak sesuai dengan masyarakat tertentu. Terakhir, karakteristik kajian sosiologi hukum adalah tidak melakukan penilaian terhadap hukum, tingkah laku yang mentaati hukum, sama-sama merupakan objek pengamatan yang setaraf. ${ }^{9}$

Dari karakteristik kajian sosiologi hukum diatas, dapat menjadi pedoman dalam menganalisis peranan sosiologi hukum dalam memberantas pungli di Indonesia ini. Untuk menemukan penyebab pungli, dapat menggunakan konsepsi Alfred Schutz tentang because motive atau disebut sebagai motif penyebab. Di dalam konsepsi ini, maka dapat dinyatakan bahwa tindakan manusia ditentukan oleh ada atau tidaknya faktor penyebabnya. Maka seseorang melakukan pungli juga disebabkan oleh beberapa faktor penyebab. Faktor penyebab itulah yang disebut sebagai motif eksternal penyebab tindakan. ${ }^{10}$

Praktik pungli adalah fenomena yang telah berurat akar di negeri ini sejak masa kolonial. Hal ini menjadi sesuatu yang persisten dari masa ke masa, termasuk pada masa pemerintahan sekarang. Banyak hasil riset selama ini menemukan bahwa rendahnya kualitas pelayanan publik selalu berkaitan dengan praktek atau pola korupsi. Bentuknya antara lain "petty corruption" atau pungli. Contoh, seorang petugas

\footnotetext{
${ }^{8}$ Soerjono Soekanto, Mengenal Sosiologi Hukum, Citra Aditya Bakti, Bandung, 1989, hal. 11.

${ }^{9}$ Zainudin Ali, Sosiologi Hukum, Sinar Grafika, Jakarta, hal. 8.

${ }^{10}$ Nur Syam, Penyebab Korupsi, sumber: http://nursyam.sunan-ampel.ac.id/?p=526, Prof. Dr. Nur Syam. M. Si, diakses pada tanggal 12 November 2018.
} 
disuap oleh warga untuk manipulasi meteran listrik atau air. Praktek ini merapuhkan kinerja di lini pelayanan publik.

Praktek ini juga merapuhkan standar pelayanan setara bagi warga. Meskipun pungli bukan kategori kejahatan luar biasa (extra-ordinary-crime) yang merapuhkan daya tahan negara, namun pungli berisiko merapuhkan produktivitas birokrasi dan kualitas pelayanan hak-hak dasar rakyat. Dengan demikian, maka pungli sulit dicegah dan diberantas, seperti sakit dan penyakit, pungli selalu bersama dalam kehidupan manusia. Seperti halnya korupsi selalu melekat pada organisasi manusia, termasuk negara. Maka di mana saja ada negara, di situ lahir praktek korupsi. Sehingga ekonom penerima Nobel, Garry S. Becker, pernah bercanda bahwa "jika negara bubar, maka praktek korupsi juga akan sirna."

Adapun beberapa faktor pendukung yang menyebabkan pungutan liar ini tumbuh subur, diantaranya ialah:

a. Faktor Individu Pelaku. Faktor individu pelaku disini adalah Aparatur pemerintah yang tidak lagi memiliki karakter integritas yang tinggi akan tanggung jawab sebagai Pelayan bagi masyarakat. Sifat tamak, sikap Moral yang kurang kuat; penghasilan yang kurang; Kebutuhan hidup yang mendesak; Gaya hidup yang konsumtif; Malas atau tidak mau kerja; Ajaran agama yang kurang diterapkan.

b. Faktor Organisasi. Kurang adanya sikap keteladanan dari pimpinan; tidak adanya kultur organisasi yang benar; sistim akuntabilitas yang benar di instansi pemerintah yang kurang memadai; kelemahan sistim pengendalian manajemen.

c. Faktor Kesempatan. Faktor kesempatan ini erat kaitannya dengan anggota masyarakat yang sedang membutuhkan dokumen kelengkapan administrasi ketika diminta dapat menyanggupi permintaan tersebut.

d. Faktor Pengawasan. Pengawasan terhadap kebijakan yang diambil oleh lembaga-lembaga atau instansi mengenai pembiayaan dalam pengurusan dokumen berbeda-beda. bahkan ketika sudah ada tulisan atau informasi "GRATIS" sekalipun tetap saja ada Oknum petugas dan masyarakat yang bermain pungli

e. Faktor Hukuman/Sanksi. Walaupun sudah ada aturan sanksi yang ditentukan tetapi prakteknya dapat diselesaikan dengan jalan damai atau pengembalian uang pungli dan berjanji tidak akan melakukan lagi.

f. Partisipasi Masyarakat rendah dalam memerangi praktik. Selama ini Pungli tumbuh dengan wajarwajar saja karena pemakluman dari masyarakat. Permintaan dana dari pihak aparat tidak dipermasalahkan oleh Masyarakat dan sudah dianggap wajar.

\section{Pendekatan Sosiologi Hukum dalam Pemberantasan Pungli pada Pelayanan Publik}

a. Teori Penanggulangan Kejahatan

Upaya yang dapat dilakukan memberantas pungli salah satunya adalah dengan cara mencegah dan menanggulanginya. Menurut teori sosiologi hukum, bahwa kejahatan akan selalu ada, jika ada kesempatan untuk melakukannya sampai berulang kali. Pelaku dan korban kejahatan berkedudukan sebagai partisipan yang dapat terlibat secara aktif dalam suatu kejahatan. Korban membentuk pelaku kejahatan dengan sengaja atau tidak sengaja berkaitan dengan situasi dan kondisi masing-masing. Antara korban dan pelaku ada hubungan fungsional. Berdasarkan pandangan tersebut, maka dapat disimpulkan bahwa pungli itu tidak dapat dihapus begitu saja akan tetapi dapat diusahakan untuk diminimalisir kejahatan itu. Menurut Bonger, dalam teori penanggulangan kejahatan, dapat di lakukan melalui metode sebagai berikut: pre-emtip, preventip dan represif. ${ }^{11}$

1) Metode Pre-emtif. Metode ini merupakan usaha atau upaya-upaya pencegahan kejahatan sejak awal atau sejak dini, yang mana tindakan itu lebih bersifat psikis atau moril untuk mengajak atau menghimbau kepada masyarakat agar dapat mentaati setiap norma-norma yang berlaku, upayaupaya tersebut dapat berupa:

a) Melakukan pembinaan kepada calon pegawai tentang larangan melakukan perbuatan yang menjadikan Masyarakat sebagai objek materialis atau lahan untuk mendapatkan uang.

b) Melakukan pembinaan moral dan integritas serta akuntabilitas kinerja seluruh pegawai.

\footnotetext{
${ }^{11}$ Bonger, Pengantar Tentang Kriminologi, PT. Pembangunan Ghalia Indonesia, Jakarta, 1981, hal. 15.
} 
c) Membuat selebaran-selebaran/banner mengenai informasi yang dianggap perlu demi mencegah kejahatan dan pelanggaran.

d) Pada tataran tata kelola, hendaknya diatur bahwa sebisa mungkin setiap jenis pelayanan publik dilakukan secara online. Hal ini belum diwajibkan dalam UU Pelayanan Publik karena sistem informasi masih boleh dilakukan secara manual. Selain lebih efisien dan transparan, layanan online akan menghindarkan terjadinya pertemuan langsung antara pemberi layanan dengan penerima layanan. Dengan demikian, tertutup pula peluang untuk melakukan pungli. Jika pun layanan terpaksa dilakukan secara tatap muka, maka dapat dibuat instrumen dan fasilitas yang berperan se-bagai pencegah pungli seperti papan tanda biaya resmi berikut target waktu penyelesaian dan kotak pengaduan. Kemudian mekanisme pembayarannya dilakukan lewat transfer bank jika jumlahnya cukup signifikan.

2) Metode Preventif, merupakan upaya yang dilakukan dengan tujuan untuk mencegah timbulnya kejahatan dengan tindakan pengendalian dan pengawasan, atau menciptakan suasana yang kondusif guna mengurangi dan selanjutnya menekan agar kejahatan itu tidak berkembang ditengah masyarakat. Upaya preventif ini pada prinsipnya jauh lebih menguntungkan jika dibandingkan dengan usaha penaggulangan secara represif. Hal ini sesuai dengan apa yang dikemukakan oleh seorang kriminolog. W. A. Bonger mengatakan bahwa "Preventing crime is better than trying to educate criminals to be good people again" (mencegah kejahatan lebih baik daripada mencoba mendidik penjahat menjadi orang baik kembali)" 12 Berdasarkan pendapat tersebut, maka dapat ditarik kesimpulan bahwa mencegah terjadinya sesuatu yang tidak diinginkan jauh lebih baik dari pada memulihkan kembali dampak dari apa yang terjadi. Upaya tersebut dapat berupa:

a) Penyuluhan-penyuluhan hukum mengenai larangan pungli oleh Ombudsman RI kepada Aparat baik formal maupun nonformal. Bekerja sama dengan Kepolisian, instansi-instansi, sekolah, LSM, Pemerintah Daerah, orangtua murid dan masyarakat. Hal ini dilakukan dengan maksud sebagai pencegahan agar pungutan liar di sektor-sektor terutamanya pelayanan publik tidak terjadi. Selain itu dari bimbingan dan penyuluhan ini diharapkan agar masyarakat menjunjung tinggi kejujuran dan kinerja yang baik.

b) Ombudsman bekerja sama dengan masyarakat membuat pos-pos pengaduan untuk meminimalisir terjadinya praktik pungli;

c) Mengikut sertakan masyarakat untuk mengubah budayanya dan bersikap "anti pungli". Dengan sikap demikian, diharapkan, masyarakat mau mencegah dan melaporkan pungli yang terjadi. Partisipasi masyarakat juga dapat diberikan dalam bentuk "memboikot" setiap acara atau undangan dari pejabat yang sering melakukan pungli. Inilah hukuman masyarakat yang benarbenar efektif dan dirasakan para pelaku. Untuk peran serta masyarakat diatur dalam pasal 41 Undang-Undang Nomor 20 Tahun 2001.

3) Metode Represif. Metode represif merupakan upaya atau tindakan yang dilakukan secara langsung untuk memberantas pungutan liar dengan "provide an action so that the perpetrators deter And do not repeat the crime again" (memberikan tindakan agar pelaku jera dan tidak mengulangi kejahatannya kembali). ${ }^{13}$ Adapun tindakan represif yang dimaksud sebagai berikut:

a) Pemanggilan Pelaku Pungli oleh Ombudsman guna diselidiki apakah dugaan Pungutan Liar benar terjadi, apabila benar ditemukan Ombudsman akan menyurati Instansinya guna memberikan sanksi bagi terlapor;

b) Untuk Aparat yang terbukti melakukan pungutan liar harus mengembalikan uang yang telah didapatnya secara Pungli;

c) Lembaga/instansi terkait sendiri mengaku memiliki aturan yang jelas untuk pelaku pungutan liar, pelaku akan dimutasi ke tempat lain, pencopotan dari jabatan, sampai dengan pemecatan apabila benar terbukti melakukan pungtan liar; 
d) Apabila terbukti melakukan pungutan liar dan telah diserahkan pada Lembaga/dinas/instansi terkait namun tidak ditanggapi secara serius, Ombudsman akan membuat pengumuman di media, misalnya Koran atau televisi lokal.

e) Dalam tataran regulasi perlu dilakukan penguatan kewenangan dari organ pengawas seperti ORI dan Aparat Pengawasan Intern Pemerintah (APIP). ORI selama ini hanya berhak memberikan rekomendasi. Hendaknya kewenangannya diperkuat agar ORI juga memiliki fungsi eksekutorial, sehingga penyelenggara layanan publik yang terbukti melalui hasil pemeriksaan melanggar kewenangan seperti pungli pasti mendapat sanksi. Demikian pula dengan APIP, agar memiliki gigi, kedudukan APIP hendaknya berada di atas lembaga yang diawasinya. Jadi, misalnya, Inspektorat kementerian dan lembaga bertanggung jawab langsung kepada Presiden atau lembaga baru, Inspektorat Nasional yang saat ini sedang diwacanakan, Inspektorat pemerintah provinsi berada di bawah Kemendagri, dan inspektorat kabupaten/kota berada di bawah pemerintah Provinsi.

b. Teori Efektifitas Penegakan Hukum

Berdasarkan teori efektivitas hukum yang dikemukakan Soerjono Soekanto, efektif atau tidaknya suatu hukum ditentukan oleh 5 (lima) faktor. Pertama; faktor hukumnya sendiri. Kedua; faktor penegak hukum, yakni pihak-pihak yang membentuk maupun menerapkan hukum. Ketiga; faktor sarana atau fasilitas yang mendukung penegakan hukum. Keempat; faktor masyarakat, yakni lingkungan di mana hukum tersebut bekerja. Kelima; faktor kebudayaan, yakni sebagai hasil karya, cipta, dan rasa yang didasarkan pada karsa manusia di dalam pergaulan hidup. ${ }^{14}$ Sehingga agar hukum tersebut berjalan efektif yang harus dilihat adalah hukum itu sendiri, dengan tujuan memberikan keadilan, kemanfaatan, dan kepastian hukum.

Efektivitas hukum adalah mengkaji kaidah hukum yang harus memenuhi syarat, yaitu berlaku secara yuridis, berlaku secara sosiologis, dan berlaku secara filosofis. Oleh karena itu, faktor-faktor yang dapat mempengaruhi hukum itu berfungsi dalam masyarakat, yaitu kaidah hukum atau peraturan itu sendiri, petugas atau penegak hukum, sarana atau fasilitas yang digunakan oleh penegak hukum, kesadaran masyarakat. Agar hukum itu berfungsi atau memiliki efektivitas maka suatu kaidah hukum harus berlaku secara yuridis, sosiologis, dan filosofis. Bila kaidah hukum berlaku secara yuridis saja, ada kemungkinan kaidah itu merupakan kaidah mati, dan jika hanya berlaku secara sosiologis dalam arti teori kekuasaan, maka kaidah itu menjadi aturan pemaksa, dan begitu pula jika kaidah hukum hanya berlaku secara filosofis, maka kaidah itu hanya merupakan hukum yang dicita-citakan. Sehingga jika dikaitkan dengan keberadaan Undang-Undang Pemberantasan Tindak Pidana Korupsi, agar Undang-Undang tersebut berjalan efektif maka harus memenuhi unsur-unsur yuridis, sosiologis, dan filosofis.

Selain menggunakan pendekatan teori sosiologi hukum diatas, upaya pemberantasan pungli setidaknya harus menyentuh kepada tiga dimensi berikut: tata kelola, regulasi, dan kultur. ${ }^{15}$ Pada tataran tata kelola, hendaknya diatur bahwa sebisa mungkin setiap jenis pelayanan publik dilakukan secara online. Dalam tataran regulasi perlu dilakukan penguatan kewenangan dari organ pengawas seperti ORI dan Aparat Pengawasan Intern Pemerintah (APIP). ORI selama ini hanya berhak memberikan rekomendasi. Hendaknya kewenangannya diperkuat agar ORI juga memiliki fungsi eksekutorial, sehingga penyelenggara layanan publik yang terbukti melalui hasil pemeriksaan melanggar kewenangan seperti pungli pasti mendapat sanksi. Demikian pula dengan APIP, agar memiliki gigi, kedudukan APIP hendaknya berada di atas lembaga yang diawasinya. Hal terakhir yang perlu diperhatikan untuk memberantas pungli secara menyeluruh adalah perbaikan kultur. Karena pungli terjadi salah satunya juga disebabkan karena permisivitas masyarakat.

\section{SIMPULAN}

Pungutan liar adalah meminta sesuatu (uang dan sebagainya) kepada seseorang (lembaga, perusahaan, dan sebagainya) tanpa menurut peraturan yang lazim. Praktik pungli telah merusak sendi kehidupan

\footnotetext{
${ }^{14}$ Soerjono Soekanto, Faktor-Faktor Yang Mempengaruhi Penegakan Hukum, Raja Grafindo Persada, Jakarta, 2008 , hal. 8.

${ }^{15}$ Antonius Galih Prasetyo, Op. Cit., hal. 51.
} 
bermasyarakat dan menyebabkan kerugian kepada masyarakat yang mengakses pelayanan publik. Di Indonesia pungli merupakan perbuatan melanggar hukum dan norma-norma yang hidup dalam masyarakat.

Sosiologi hukum bertujuan untuk menjelaskan mengapa pungli terus terjadi didalam kehidupan sosial masyarakat, antara lain dengan menganalisis faktor-faktor yang mempengaruhi pungli dan upaya untuk memberantas pungli. Pemberantasan pungli dalam perspektif sosiologi hukum dengan menggunakan teori penanggulangan kejahatan dan teori efektifitas hukum. Disamping itu perlu juga upaya pemberantasan pungli setidaknya harus menyentuh kepada tiga dimensi antara lain: tata kelola pemerintahan yang baik, penguatan regulasi, dan perbaikan kultur.

\section{DAFTAR PUSTAKA}

\section{Buku}

Bonger, Pengantar Tentang Kriminologi, PT. Pembangunan Ghalia Indonesia, Jakarta, 1981.

Soerjono Soekanto, Mengenal Sosiologi Hukum, Citra Aditya Bakti, Bandung, 1989.

Soerjono Soekanto, Faktor-Faktor Yang Mempengaruhi Penegakan Hukum, Raja Grafindo Persada, Jakarta, 2008.

Zainudin Ali, Sosiologi Hukum, Sinar Grafika, Jakarta, 2012.

\section{Peraturan Perundang-Undangan}

Undang-undang Nomor 28 Tahun 1999 tentang Penyelenggaraan negara yang bersih dari korupsi, kolusi, dan nepotisme (KKN)

Undang-Undang Nomor 20 Tahun 2001 tentang Pemberantasan Tindak Pidana Korupsi

Undang-Undang Nomor 37 Tahun 2008 tentang Ombudsman Republik Indonesia

Undang-undang Nomor 25 Tahun 2009 tentang Pelayanan Publik

Peraturan Presiden Nomor: 87 tahun 2016 tentang Satgas Saber Pungli

Jurnal/Makalah

Moh Toha Solahuddin, Pungutan Liar dalam Perspektif Tindak Pidana Korupsi, Majalah Paraikatte, Vol. 26, Triwulan III, 2016.

Antonius Galih Prasetyo, Memberantas Pungli Secara Sistemik, Inagara Magazin, Vol I No. 2, Desember 2016.

Eko Budi, Meningkatkan Kinerja UPP Kabupaten/Kota dalam Memberantas Pungli Melalui Strategi Pembinaan dan Penindakan, Makalah diberikan pada Raker Lintas Unit Kerja Saber Pungli sePropinsi Jambi, tanggal 14-15 November 2018.

Reza Iswanto, Kebijakan Nonpenal oleh Badan Narkotika Nasional Provinsi Jambi terhadap Penyalahguna Narkotika, Jurnal Wajah Hukum, Volume 2 Nomor 2 (Oktober 2018).

\section{Website}

Data dari Satgas Saber Pungli Pusat tahun 2016 - 2018, sumber: https://polkam.go.id/tiga-tahun-berjalansatgas-saber-pungli-lakukan-7-439-ott/ diakses tanggal 2 Februari 2019.

Hisam Sam, Pengertian Pungli dan Faktor Penyebabnya, sunber https://www.dosenpendidikan.com/pungutan-liar-pungli-pengertian-faktor-penyebab-tindak-pidana/, diakses tanggal 2 Februari 2019.

Nur Syam, Penyebab Korupsi, sumber: http://nursyam.sunan-ampel.ac.id/?p=526, diakses pada tanggal 2 Februari 2019. 